\title{
A Comparative Study of the Simple Clause Structure of Kyerepong (Okere), Akuapem Twi, and English
}

\author{
Ebenezer Asinyor \\ Lecturer, Department of Liberal Studies \\ Koforidua Technical University, Koforidua \\ Ghana
}

Edward Owusu, PhD

Senior Lecturer, Department of Communication Studies

Director of Quality Assurance and Academic Planning Directorate

Sunyani Technical University, Sunyani

Ghana

\author{
Asuamah Adade-Yeboah \\ Senior Lecturer, and Head, Department of Communication Studies, \\ Christian Service University College, Kumasi, Ghana \\ Solomon Ali Dansieh, PhD \\ Senior Lecturer, Department of General and Liberal Studies \\ Director of Research and Academic Programmes \\ Wa Technical University, Wa \\ Ghana
}

\begin{abstract}
This paper compares the simple clause structure in three languages of Kyerepong (Okere), Akuapem Twi and English. Again, the paper discusses how the structures mark focus and topic; and how they are used in copula and locative constructions. The paper comprises seven main parts. The first part gives a brief linguistic background of the two Ghanaian languages. The second part looks at the constituent order of the three languages; and the third considers the phonological processes involved. The remaining parts (which constitute the hub of the paper) focus on how the simple clause in these three languages is used in focus, topic, copula and locative constructions.
\end{abstract}

Keywords: Simple Clause Structure, Akuapem Twi, Kyerepong (Okere), Locative Constructions, Copula

\section{Introduction}

The paper compares the simple clause structure of three languages of English, Akuapem (Ak.) Twi and Kyerepong (Okere), and identifies how their linguistic forms are produced to express meaning. The designation, Guan, describes a group of closely related languages mostly in Ghana spanning from Winneba in the Central Region to Bole in the Northern Region (Bramson, 1981). Steward (1966) divides the Guans into two main groups: a southern group comprising Awutu and Kyerepong; which has Late, Anum, and Boso as sub-dialects and a northern group mainly of Gonja. The main Kyerepong towns include Abirew , Dawu, Awukugua (Okereso), Adukrom (Esiz̃so), Abonse, Apiredi and Asesecso all located in the eastern part of the Eastern Region of Ghana. Moreover, in places such as Amamfro, Kwadako, Sanfoano, Twum Guaso, Amashi and Kongo, all along a common road that joins the Tinkong-Adawso road leading to Accra, Kyerepong, (commonly referred to by the people as Okere) is spoken. Tompkins et al. (2002) relate that the name Gua means to run away; and it is used to describe the Guan people who ran away from ancient Ghana in the north and settled in the present day Ghana. According to Dan Botwe, Member of Parliament for Okere, the early Kyerepongs were chiefly farmers who did not get involved in the coastal trade with the Europeans. They settled on the mountains because they were peaceful and eschewed warfare, and the mountains provided them the security they wanted.

The people of Koforidua, where the second language in this study is spoken, are mainly from Juaben in the Ashanti Region of Ghana. Legends have it that during the time of Nana Dokua, some of the Juabens revolted against the Golden Stool of Ashanti. The rebels who were led by their chief, Nana Kwaku Boateng, fled and settled at places such as Kyebi, Kwabeng, Tafo, Asamankese and other parts of Akyem Abuakwa all in the Eastern Region of Ghana. Afterwards, some chiefs granted the Juabens a permit to settle on a land which was later called New Juaben with Koforidua as its capital. 
Akuapem Twi has been exposed to a lot of scholarly works since the time of the Christian Missionaries. Twi extends the boarders of New Juaben to many parts of the Eastern Region as lingua franca. Twi is written and taught in schools and used in many domains such as in religion and commerce. Though Kyerepong is spoken in a number of towns, it has not been reduced to writing and reading. The reason is most of the speakers speak Akuapem Twi as well, so the Christian Missionaries focused on Twi which had a broader speaker base. Hence, Kyerepong's domain of use is restricted to their social milieu. In churches and in schools, Akuapem Twi is the medium.

Regarding scholarly work, a lot has not been done in connection with Kyerepong (Okere). Tompkins et al. (2002) did a sociolinguistic survey of the Hill Guan languages and reported that a primer for standard Guan for the Hill varieties and a two-book primer series had been developed, but had not been published. Bramson (1981) did a comparative study of Kyerepong varieties spoken at Abiriw, Dawu and Apiredi. Also, Kropp Dakubu (1988) and Grimes (1992) identified three dialects of Hill Guan namely Late, Kyerepong or Okere and Anum/Boso while Ofori (2004) discussed vowel harmony in Late.

\section{The Nature of the Data}

The data for this study comprise native-speaker descriptions of Bowerman and Pederson's (1993) Topological Relations Pictures Series, A story about what is planned for the next day, a brief family history, some responses from the interview sessions we had with native speakers, and a Twi story entitled "Kofi ne Adom." All these field data were collected between September and December 2014.

\section{The Simple Clause}

The simple clause is usually explained in the literature as containing one clause which expresses a single idea and has one verb phrase. Languages may have different clausal forms to express different structures such statements, copula constructions and locative constructions and to express what is of communicative interest to the speaker linguistically referred to as focus (Chiarcoset al., 2009). The following section concentrates on how the three languages Okere, Akuapem Twi and English use such forms to express different meanings. In describing the forms, the following clausal elements: subject (S), verb (V), object (O), complement (C) and Adjunct (A) were used.

\subsection{Constituent Order}

The three languages under comparison are not case languages. They depend on a specific order in relation to the verb to mark case. The entity that is placed before the verb functions as the subject; the one after the verb functions as the object. In the case of English, it is only the pronominal system that shows differences in gender and case. In sentence formation, Kyerepong (Okere), Akuapem Twi, and English are all SVO languages. To form a statement, these languages can use the basic sentence order SVO, as well as the variants: SVC, SVA, SVOA and SVOC as in the following examples:

Kyerepong (Okere)

$\begin{array}{lll}\text { 1. E-n-ku } & \text { bá } & \text { sle yo.(SVOA) } \\ \begin{array}{c}\text { 1PL.SUBJ-PERF-cut (V) } \\ \text { "It is walled." }\end{array} & \text { wall (O)take } & \text { around (A) }\end{array}$

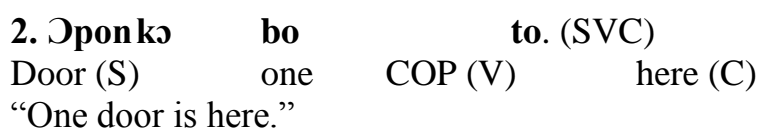

3. Inde, me-woe afuru te. (ASVA) yesterday (A) 1SG.SUBJ-went (V) farm inside (A) "Yesterday, I went to the farm."
4. Mè-bó
tei. $(\mathrm{SVO})$
1SG.SUBJ/FUT-do (V) food (O)
"I will prepare food."

\section{5. À-nć-gyãĩ-m o, me-de-hũ.(SVO)}

3SG.SUBJ-PROG-search(V)-3(O) INT 1SG.(S)-AUX-see(V)

"Whether s/he is searching for her/him, I don't know."
6. $\dot{\varepsilon}$-nغ̀-dã́
so nkangyẽẽ. (SOC)
1PL.SUBJ-PERF-hit(V)
top sheets $(\mathrm{C})$
"It has been roofed."

Akuapem Twi

\section{Da biara a o-be-ko sukuu no, (ASVA)}




\title{
Day every DET s/he.SUBJ-FUT-go(V) school(A) DET \\ o-de Adom di n'-akyi. (SVOC) \\ s/he.SUBJ-take (V) Adom (O) eat 3SGPOSS-back (C) \\ "Every day, he goes to school with Adom."
}

Constituents in the simple clause are positioned and shaped by some phonological processes to express meaning and functions. Some of the processes and meaning strategies are conflation/agglutination, vowel harmony, morpheme or segment deletion, focus and topic.

\subsection{Conflation/Agglutination}

In both Okere and Akuapem Twi, a pronoun subject and the verb conflate into one word as in Énku,we have cut, in

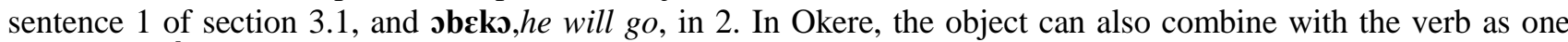
word as in À-nć-gyãĩ-m, he is searching for him, where - $\mathbf{m}$ is the object. This phenomenon does not happen in Akuapem Twi nor in English. There are some cases where some morphemes also conflate or fuse into one in the clause structure. For example, $\dot{\varepsilon}$-nغ̀ in sentence 6 is made up of غ̀né,which is the first person plural subject pronoun and $\mathbf{n} \dot{\boldsymbol{\varepsilon}}$, the perfect marker. The second syllable in the pronoun is fused with the perfect marker into one; however, the high tone in the second syllable of the pronoun is transferred onto the first syllable $\varepsilon$. This phenomenon can also be explained in terms of elision in section 3.3.

\subsection{Morpheme/Segment Elision}

In the two Ghanaian languages under comparison, a phonological process of segment elision takes place in the structures to optimize pronunciation. For example, in sentence 1 of this section (3.3), the pronoun $\mathbf{E}$ is a clipped form of the first person plural subject غ̀né. The perfect verb n⿳亠े is entirely deleted, so instead of:

\author{
Éné-nè-ku \\ 1PL.SUBJ-PERF-cut; \\ we have: \\ Énku, where the syllable né in Ené is deleted.
}

We notice that the high tone on the deleted morpheme is transferred onto the $\mathbf{E}$.

\subsection{ATR Vowel Harmony (VH)}

One of the prominent phonological processes that take place in Okere and Akuapem Twi clauses is Advanced Tongue Root [+ATR] harmony, a phenomenon which is non-existent in English. In some languages, vowels in words are expected to share some linguistic properties. These properties determine the distribution of vowels in the words of these languages (Katamba, 1993). The restriction of the distribution of [ATR] vowels is meant to aid articulation and meaningful communication. In [ATR], if the tongue root advances in the production of a vowel, the vowel is described as [+ATR]. On the other hand, if the tongue root retracts, the vowel is [-ATR]. Based on this phenomenon, two groups of vowels can be identified to operate in both Akuapem Twi and Okere:

$$
\begin{aligned}
& \text { [+ATR] /i, u, e, o, æ/ } \\
& \text { [-ATR] /I, }, \varepsilon, ~, ~
\end{aligned}
$$

The transition fromEné-nè-kutoÉnkualso illustrates the phenomenon of VH. The default $\boldsymbol{\varepsilon}$ in $\boldsymbol{E}$ né is changed to Einanticipation of the high back vowel $-\mathbf{u}[+\mathrm{ATR}]$ in kù, cut, which has assumed its [+ATR] properties, hence, $\mathbf{E}$ instead of $\boldsymbol{\varepsilon}$.Other examples of $\mathrm{VH}$ are expressed below:

Kyerepong (Okere)

Gbei ase koto ogbolu te

Dog RP kneel pan inside

We notice that all the words in the sentence above have vowels from either of the [ATR] groups.Gbeiis [+ATR],

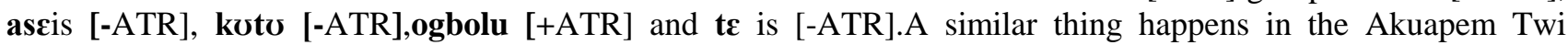
example in sentence 2 under Section 1.3.

Da biara a sbeks sukuu no,

$\mathrm{Da}$ is [-ATR], biara [+ATR], sbeks [-ATR] and sukuu [+ATR].

\subsection{The Structure of Okere and Akuapem Twi Noun Phrase}

The noun phrases in the simple clause of the Ghanaian languages in this paper have the structure: Noun+ (Adjective) +Determiner as in sukuu no (Ak. Twi), the school and Opon ko (Okere),one door in examples 2 and 3 of section 3.1. The modifier adjective is optional and the determiner is placed after the noun head. The noun head assumes the first position in the phrase and any modifier comes afterwards. This structure topicalizes the head as an 
entity attention should be drawn to first. English, on the other hand, has the head NP as the last element with the determiner and the adjective (if present) preceding it in that order respectively.

\subsection{Focus in Okere and Akuapem Twi}

Chiarcos et al. (2009) explains that focus signifies newor newsworthyinformation a sentence expresses. Crystal (2003) as cited in Dorvlo (2008) also relates that focus is a term that is used in sentence analysis to differentiate between assumed information and the information which holds the speakers' communicative interest. Dorvlo (2008) further explains that the focusing strategy is employed as a corrective measure by the speaker in stressing the information the speaker believes is the case that is different from what the addressee thinks is the case.

The two Ghanaian languages in this comparative study deploy focus strategies in their clause structures to express communicative interest and corrective measures as explained above. Okere seems to have two particles, dé and mó, for marking focus. The analysis of the data indicates that the differences in focus realization correspond to semantic differences. It is observed that the particle dé is used to mark argument focus and it usually precedes the entity that is focused. On the other hand, mó seems to be used as a predicate focus marker, and the context of use indicates that dé and mó can be used as variants to focus on non-human arguments. However, dé is solely used to focus on human arguments. Examples with dé and mó are shown below:

\begin{tabular}{|c|c|c|c|c|}
\hline \multirow{2}{*}{\multicolumn{2}{|c|}{$\begin{array}{l}\text { 1. Dé me } \\
\text { FOC 1SG.SUBJ twú } \\
\text { "It is me who gave it to my child." }\end{array}$}} & $\begin{array}{l}\text { hг̃ } \\
\text { give }\end{array}$ & \\
\hline & & & & \\
\hline $\begin{array}{l}\text { 2. Ené } \\
\text { 1PL.POSS }\end{array}$ & $\begin{array}{l}\text { nenyẽ -nè } \\
\text { grandfather-PL }\end{array}$ & DET & $\begin{array}{l}\text { a, } \\
\text { FOC }\end{array}$ & mó \\
\hline Edewu & a $\quad$ né & omo & peq & yi \\
\hline Dewu & COMP & 3.PL & all & live \\
\hline
\end{tabular}

In the example 1 of section 3.6, the focusing of mé by the marker Dé implies that it is the NP mé not anyone else who gave it to the recipient. The focus marker on the first person subject pronoun, therefore, is used to perform a corrective measure. The marker mó,however, focuses on the clause, $\boldsymbol{E} \mathbf{d e w u}$ a $\mathbf{n} \boldsymbol{\varepsilon} \mathbf{\jmath m o} \mathbf{p} \boldsymbol{\varepsilon} \boldsymbol{\varepsilon} \mathbf{y i}$, to indicate that it was Dewu, not anywhere else, the grandfathers lived.

Comparatively, Akuapem Twi has ná as its focus marker which can appear either clause initial or medial as examples 3 and 4 of section 3.6. Usually, if the focus is in the middle of the clause, the marker takes a low tone as shown in example 4 of section 3.6.

\section{Ná Kofi re-sa. \\ FOC Kofi PROG-dance \\ "Kofi was dancing."}

\section{4. [[Sá nà] Kofi re-sa.] \\ Dance FOC Kofi PROG-dance \\ "It was dance (that) Kofi was dancing."}

The example 3 of section 3.6 indicates that Kofi was actually dancing at the time seen, but was not doing any other thing. This meaning is evident in the example 4 (of 3.6) which vociferously insists on the fact that Kofi was dancing. This insistence can be an aggressive reply to someone who has been denying that Kofi was doing.

English does not employ focus the way Ghanaian languages do. Focus operates on the clause in English. Instead of a particular focus marker, English employs sentence accent to mark focus (Krifka, 2006). Usually in individual words, it is a single syllable that receives a primary stress where the syllable is produced with a higher pitch more than the surrounding syllables. Any single word in the clause, whether lexical or functional can be focused. The syllable that receives primary stress, in the focusing word, marks the focus in the clause. Attention is then drawn to it to indicate the communicative interest of the speaker which is different from that of the addressee's. For example, in sentence 5 (of 3.6), the stress (shown by bold print) on the verb indicates that the speaker means that the verbal action is what actually took place, but not any other thing the second interlocutor may be thinking of. In sentence 6 (of Section 3.6), the speaker means that Michael is not a friend of John but a brother. The speaker does this by stressing the word, brother.

1. He stole my book.

2. Michael is the brother of John. 


\subsection{Topic Construction}

Dorvlo (2008) explains that topic is a function that is assigned to an element that is considered to be what the message is about in the clause. In other words, topic is the entity that a speaker identifies and about which information is given (Krifka 2006). This constituent element is fronted to the left periphery of the clause. All the three languages in comparison are SVO (subject-verb-object) languages. Hence, their unmarked topic is the default subject in the clause which can either be human or non-human. However, because of communicative importance, certain elements other than the unmarked subject can be in the topic position. In the example 1 of section 3.6, the unmarked form will be: Enesĩ kya, We have built a house, wherekya is the object. However, the marked form where the house is fronted is chosen because the native speaker considers the house to be the topic which has the rest of the information as comments. In the second example (3.6), the unmarked structure is: Enkã $\mathbf{c d e t \varepsilon , ~ w h e r e ~}$

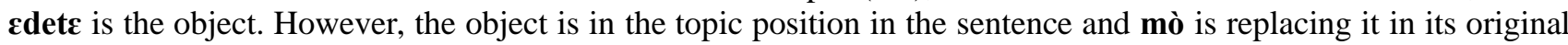
slot.

Kyerepong (Okere)

1. Kya ne ene-sĩ $\varepsilon$.

House is 3PL.SUBJ-build

"House is what we have built."

2. Edetza, $\quad$ n-kã mo.

Mat DEF, 1PL.SUBJ-lay 3SG.OBJ

"The mat, we have laid it."

Adverbial phrases indicating time seem to occupy the topic position as an unmarked structure in Okere. It is not usual for one to put time indications, for example, in the topic position in the sentence 1 of section 3.7, in the comment or the clause final position in 2 . The second sentence is not preferred.

3. Inde, mè-wóè afuru te.

Yesterday, 1SG.SUBJ-went farm in

"Yesterday, I went to the farm."

4. Mè-wóè afuru te inde.

1SG.SUBJ farm in yesterday

"I went to the farm, yesterday."

This phenomenon of fronting the adverbial time indicator to the left periphery operates in Akuapem Twi too as an unmarked choice as in:
Ennora,
me-ko-s
afuo-m.
Yesterday, 1SG.SUBJ-go-COMPL farm-in
"Yesterday, I went to the farm."

English is flexible and can front almost any constituent to the topic position as happening below:

[John] topic [wrote the examination early in the morning.] comment

[The examination] topic [was written early in the morning by John.] comment

[Early in the morning] topic [John] topic [wrote the examination] comment

[John], topic early in the morning, wrote the examination.

We notice from the noun phrase and topic construction analyses above that the Ghanaian languages prefer the unmarked position of what is communicatively important to be the at the left periphery. Any other elements follow.

\subsection{Copula Construction}

Following Dorvlo (2008), equative constructions and predicative possessive constructions are discussed under copula constructions under this section. Equative structures are constructed with the verb dé in Kyerepong (Okere), yè in Akuapem Twi and a form of be in English depending on the number of the pre-verbal NP in the English construction and the tense of the construction. The forms in the two Ghanaian languages are the same irrespective of whether the pre-verbal NP is singular or plural and the tense of the construction is past or present. If the two arguments are NPs, their positions can be swapped with a determiner on the fronted attribute. To indicate past, the first NP is preceded by ná in Akuapem Twi and mó in Okere. This construction can also be interpreted as focus marking. 
Kyerepong (Okere)

1. Kofi dé osukuu-ni.

Kofi is student-NOM

"Kofi is a student."

2. Osukuu-ni a de Kofi.

school-NOM DET is Kofi.

The student is Kofi."
3. Mó
Kofi de
osukuu-ni.
COMPL Kofi is
"Kofi was a student.

Akuapem Twi

4. Kofi ye Okua-fo
Kofi is farmer-NOM
"Kofi is a farmer."

5. Okua-fo no ye Kofi.

Farmer-NOM DET is Kofi.

"The farmer is Kofi."

6. Ná Kofi ye okua-fo.

COMPL Kofi is famer-NOM

"Kofi was a farmer."

In English, the finite forms of thebe verb can be used to form equative constructions.

- Kofi is/was a student.

- The men are/were farmers.

- I am a teacher.

\subsection{Predicative Possessive Constructions}

Predicative possessive construction is marked with bò in Kyerepong (Okere), wò in Akuapem Twi and English uses any of the form of the verb have. The bò in Okere and w⿳亠े in Akuapem Twi have the basic sense of stay in the temporary sense where the entity is assumed to be at a physical location so that one can find the entity located there if he is being searched for as in:

Kyerepong (Okere)

1. Kofi bò tó

Kofi stay here.

"Kofi is here."

Akuapem Twi

2. Kofi wò há

Kofi stay here

"Kofi is here."

It is these stay verbs that are interpreted as have in English and used as predicative possessive constructions. In the three languages, the NP possessor subject precedes the verb and the entity possessed, which functions as the object, follows:

\section{Kyerepong (Okere)}

\section{Me bò}

1SG.SUBJ stay house.

"I have a house."
2. Anyaa
bò
ebie-nè nyṍ.

Man DET stay child-PL

"The man has two children."

Akuapem Twi.

3. Me wò nua. 
1SG.SUBJ stay brother

"I have a brother."

$\begin{array}{llll}\text { 4. Papa no } & \text { wò } & \text { n-nan } & \text { bebree. } \\ \text { Man DET } & \text { stay } & \text { PL-house } & \text { many }\end{array}$

"The man has a lot of houses."

\subsection{Locative Constructions}

The simple clause can also be used to produce locative constructions in Okere and Ak. Twi. Dorvlo (2008) explains that locative constructions are the answers produced when the question where is $x$ is asked. In the answer, there is a locative verb and a postpositional phrase made up of an NP which constitutes the Ground, the location of the object and the postposition word which is sometimes explained to be a body part which has been grammaticalized.

From the data elicited by means of the Topological Relation Picture Series (TPRS) (Bowerman \& Pederson, 1993), it is noticed that Kyerepong (Okere) has bò,be located; Ak. Twi has wò, be located and English has a form of be as unmarked locative verbs. The table below shows the marked locative verbs in Okere and Akuapem Twi

Table 1: Locative Verbs of Kyerepong (Okere) and Akuapem Twi

\begin{tabular}{|c|c|}
\hline \multicolumn{2}{|c|}{ Locative Verbs } \\
\hline Kyerepong (Okere) & Akuapem Twi \\
\hline Kã & Dà \\
\hline Yélí & Gyìnà \\
\hline Kótó & Kòtò \\
\hline Kplé & Sì \\
\hline Kyàlè & Nàm \\
\hline Tálé & fàlè/fam \\
\hline 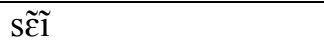 & 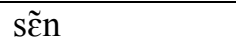 \\
\hline Tù & Tó \\
\hline kpưss̀̀ & Twéré \\
\hline wóré & hyغ̀ \\
\hline bété & $\mathrm{ben}$ \\
\hline Yí & Tè \\
\hline
\end{tabular}

The locative verbs in each row in the Table 1 have similar meanings. Each pair under the two languages is analysed concurrently. Kã is usually used for inanimate things and dead bodies lying somewhere. If the subject is alive, the unmarked bò or dè,sleep/lie, is used. However, in Akuapem Twi, dà can be used for both animate and inanimate. Yélí and gyìnà assume the subject to be vertical in posture, while kótó (Okere) and kòtò (Twi) indicate that the subject is bent. Kplé and sì give the idea that the entity is vertical, solid and firmly planted on the located place. Usually, buildings and trees are associated with kplé and sì. Objects that are slow and close to the ground are described with kyàlè and nàm. However, nàm in Twi can be used to describe both human and non-human. More so, things located very close to the ground with a flat body part attached to a surface are described with tálé (Okere) and tàlè (Twi).

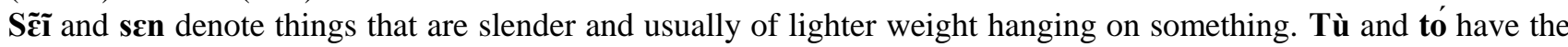
sense of juxtaposing two things, so one lies beside the other. Kpòsè and twéré bring to mind a tall object which is supported by a firmly planted object. On the other hand, wóréand hyغ̇ presupposes that the entity is housed in an enclosed location, but bété and ben are used to refer to one entity assuming a position close to another. Yí and tè indicate a position directly above the ground. The marked locative verbs are exemplified below:

Kyerepong (Okere)

$\begin{array}{llllll}\text { 1a.Atere } & \text { ko } & \text { kã } & \text { edeta } & \text { a } & \text { yó. } \\ \text { Spoon one } & \text { lie } & \text { mat } & \text { DET } & \text { skin } & \end{array}$

"One spoon is near the mat."

\begin{tabular}{|c|c|c|c|c|}
\hline $\begin{array}{l}\text { Akuapem Twi } \\
\text { 1b. Atere }\end{array}$ & baako & dà & keté & no \\
\hline Spoon & one & lie & mat & DET \\
\hline
\end{tabular}

Kyerepong (Okere)
2a. Akasini
nso yélí
abie a
esite.
Girl some too stand chair DET front
"A certain girl too is standing in front of a chair."

Akuapem Twi
2b. Ababaa-wa bi
nso
gyina agongua no
anim. 
Girl-DIM some too stand chair DET front

Kyerepong (Okere)

"A certain girl too is standing in front of a chair."

3a. Anya a kótó abie a ensi.

Man DET kneel chair DET back

Akuapem Twi

"The man is kneeling behind the chair."

$\begin{array}{rcclcl}\text { 3b. Pbarima } & \text { no } & \text { kòtò } & \text { agongua } & \text { no } & \text { akyi. } \\ \text { Man } & \text { DET } & \text { kneel } & \text { chair } & \text { DET } & \text { back }\end{array}$

"The man is kneeling behind the chair."

Kyerepong (Okere)

$\begin{array}{llllll}\text { 4a. } & \text { Mo } & \text { bá } & \text { ko } & \text { kplé } & \text { site. } \\ & \text { 3SG.POSS } & \text { hand } & \text { one } & \text { stand } & \text { floor }\end{array}$

"One hand of his is on the floor."

Akuapem Twi

$\begin{array}{lllll}\text { 4b. Ne } & \text { nsa bako si } & \text { fam. } \\ & \text { 3SG.POSS } & \text { hand one stand } & \text { floor }\end{array}$

Kyerepong (Okere)
5a. Abi
Abi né-kyàlè
bò kya-a
yó.
Snail PROG-crawl PREP room-DET skin
"A snail is on the wall of the room."

Akuapem Twi

5b. Nwa nam dan no ho.

Snail walk room DET skin

Kyerepong (Okere)

"A snail is on the wall of the room."

6a. Abi tálé kya a yó.

Snail attach room DET skin

"A snail is on the wall of the room."

Akuapem Twi

$\begin{array}{llllll}\text { 7a. } & \text { Nwa } & \text { tàlè/fam } & \text { dan } & \text { no } & \text { ho. } \\ & \text { Snail } & \text { attach } & \text { room } & \text { DET } & \text { skin }\end{array}$

"A snail is on the wall of the room."

Kyerepong (Okere)

$8 \mathrm{a}$.

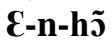 \\ 1PL.SUBJ-PERF-take flag \\ "A flag hangs on a stick."}

Akuapem Twi

$8 \mathrm{~b}$.

\section{Ye-de}

1PL.SUBJ-take flag

"A flag hangs on a stick."

Kyerepong (Okere)

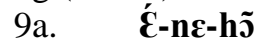
1PL.SUBJ-PERF-take
Kpokpo
Wall
a
DET skin
akpose wo-tù.

$$
\text { ladder PERF-lie }
$$

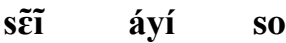

hang tree upper surface

"The ladder is leaning on the wall."

Akuapem Twi

$9 b$.

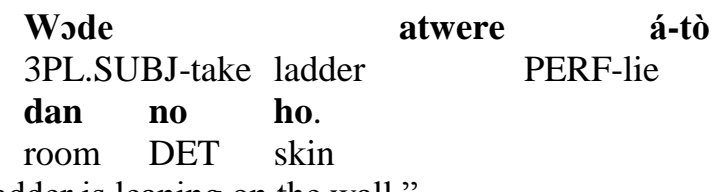

"The ladder is leaning on the wall."

Kyerepong (Okere)

10a. É-ne-tsu ekpose yó. 
Akuapem Twi

1PL.SUBJ-PERF-take lean skin

"They have propped it against the wall."

$10 \mathrm{~b}$.

Yede

a-twéré hó.

1PL.SUBJ-take PERF-lean skin

Kyerepong (Okere)

"They have propped it against the wall."

11a. Awólé woré baage té.

Book enter bag interior region

"The book is in the bag."

Akuapem Twi

$\begin{array}{lllllll}\text { 11b. } & \text { Nhoma no } & \text { hye } & \text { baage } & \text { no } & \text { mu. } & \\ \text { Book } & \text { DET } & \text { enter } & \text { bag } & \text { DET } & \text { interior region }\end{array}$

"The book is in the bag."

Kyerepong (Okere)

12a. Atere a bet $\varepsilon$ edete a yó.

Spoon DET near mat DET skin

Akuapem Twi

"The spoon is near the mat."

12b. Atere no ben kete no hó.

Spoon DET near mat DET skin

Kyerepong (Okere)

"The spoon is near the mat."

$\begin{array}{lllll}\text { 13a. } & \begin{array}{l}\text { Aberande } \\ \text { Young man }\end{array} & \text { a } & \text { àyí } & \text { sétè. } \\ \text { sit } & \text { floor }\end{array}$

"The young man is sitting on the floor."

Akuapem Twi

13b. Aberante no tè fam.

young man DET sit floor

"The young man is sitting on the floor."

From the English expressions under each glossing of section 3.10, it is observed that English often uses a relational verb is to indicate location. The semantic sense in locative construction involving an entity physically identified in relation to ground is not well captured by relational verbs. For example, is in: The book is in the bag sounds nebulous. The verb, is, can express many ideas about the book. It is the prepositional structure that helps us to understand the verb, is. However, in the Twi expression,

$\begin{array}{llllll}\text { Nhoma no hye baage } & \text { no } & \text { mu. } & \\ \text { Book } & \text { DET enter } & \text { bag } & \text { DET interior region } \\ \text { "The book is in the bag." } & & & \end{array}$

the verb hye has a basic sense of location. This is proven by the fact that without the rest of the construction, only the NP Nhoma, and the verb hysare enough for one to get the sense of the construction.

\section{Conclusion}

The paper has attempted to compare the semantics of the simple clause in Kyerepong (Okere), Akuapem Twi and English. However, we feel that a more detailed study needs to be done, especially in Kyerepong since the language is yet to receive formal documentation. The necessity for this work is evidenced by the fact that a lot of linguistic forms were left untouched since they do not form a core part of the current study. It is our hope that this paper will contribute meaningfully to scholarship, and open up more areas for detailed study.

\section{References}

Ansah, M. A. (2002). The function of tones in Lat grammar. In M. E. Kropp Dakubu and E. K. Osam (eds.), Studies in the Languages of the Volta Basin I, pp. 197-203. Legon: Linguistics Department.

Bramson, D. A. (1981). Varieties of the Kyerepong spoken in Abiriw/Dawu and Apiredi. PhD Thesis, Department of Linguistics, University of Ghana.

Bowerman, M. \& Pederson, E. (1993). Topological Relations Pictures Series. In Eve Danziger and Deborah Hill (eds.), Manual for the space stimuli kit 1.2. pp. 40-50 Nijmegen: Max Planck Institut für Psycholinguistik, Cognitive Anthropology Research Group. 
Botwe, D. K. (2010). <www.okere.ghanamps.gov.gh/about> May 27, 2014.

Chiarcos, C.; Fiedler, I.; Grubic, M.; Haida, A.; Hartmann, K.; Ritz, J.; Schwarz, A.; Zeldes, A.; \& Zimmermann, M. (2009).Information structure in African languages: Corpora and tools. In Proceedings of the EACL Workshop on Language Technologies for African Languages, pp. 17-24. Greece: Association of Computational Linguistics. Crystal, D. (2003). English as a global language (2 ${ }^{\text {nd }}$ ed.). New York: Cambridge University Press.

Dorvlo, K. (2009). Focus in Logba. The Journal of West African Languages 36 (1-2), 91-106.

Dorvlo, K. (2008). Grammar of Logba (Ikpana). The Netherlands: LOT Janskerkhof 13.

Grimes, B. (1992). Ethnologue: Languages of the world. Dallas, Texas: Summer Institute of Linguistics.

Katamba, F. (1993). Phonology. London: Longman.

Krifka, M. (2006). Basic notions of information structure. In Féry, Fanselow and Krifka Manfred (eds.), Interdisciplinary Studies on Information Structure.

Kropp Dakubu, M. E. (1988). Volta Comoe. In M. E. Kropp-Dakubu (ed.), The languages of Ghana, 50-90. London: Kegan Paul International for the International African Institute.

Ofori, K. (2004). Vowel harmony in Larteh-A descriptive analysis. In M. E. Kropp Dakubu and E. K. Osam (eds.), Studies in the Languages of the Volta Basin II, pp. 250-258. Legon: Linguistics Department.

Stewart, J. M. (1966). Comparative African Wordlists no. 1: Awutu, Larteh, Nkonya, and Krachi. Legon, Ghana: Institute of African Studies.

Tompkins, B.; Hatfield, D. H. \& Kluge, A. (2002). Sociolinguistic Survey of the Gua Language Community. Ghana: Sil International.

\section{APPENDICES}

\section{List of Abbreviations}

$\begin{array}{ll}\text { Ak. } & \text { Akuapem } \\ \text { PL } & \text { plural } \\ \text { SUBJ } & \text { subject } \\ \text { SG } & \text { singular } \\ \text { first person } & \\ \text { second person } & \\ \text { third person } & \\ \text { FUT } & \text { future } \\ \text { PROG } & \text { progressive } \\ \text { AUX } & \text { auxiliary } \\ \text { PERF } & \text { perfect } \\ \text { DET } & \text { determiner } \\ \text { POSS } & \text { possessive } \\ \text { [ATR] } & \text { advanced tongue root } \\ \text { VH } & \text { vowel harmony } \\ \text { RP } & \text { relative pronoun/particle } \\ \text { FOC } & \text { focus } \\ \text { COMP } & \text { complementizer } \\ \text { NOM } & \text { nomilizing suffix } \\ \text { DIM } & \text { diminutive suffix }\end{array}$

\section{Kyerepong descriptions of TRPs according to their numbers}

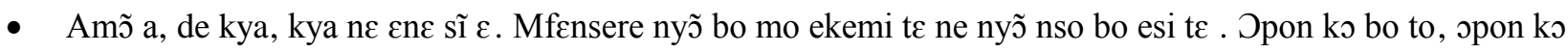

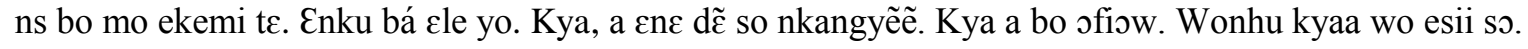

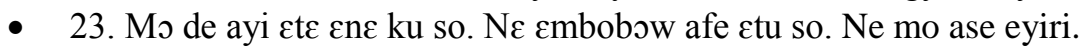

- 24. Mo nso de $\varepsilon$ dete. Atere kã yo. Atere a, eko kã ase ne eko kã yo.

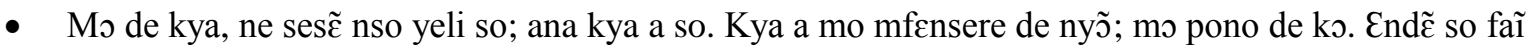

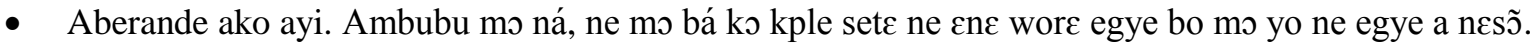


- 47. Mo nso de gbei. Gbei a se akoto ogbolu te ne adwu wokye mo yo.

- Mo nso de kya. Ne bo te se Mpepefo asore kya, ne ayi kple yo. Ensi mo se Mpepefo le a ngo.

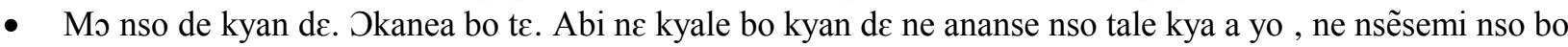

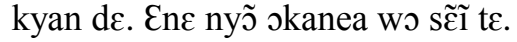

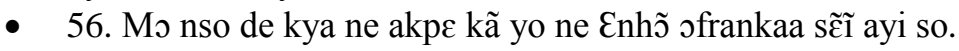

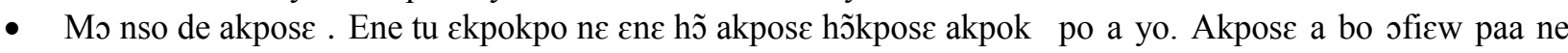
enetsu ekpose yo.

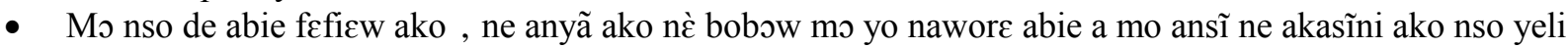

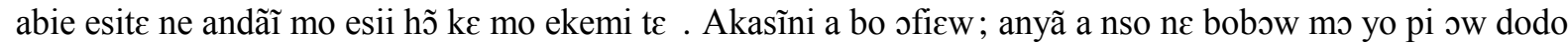

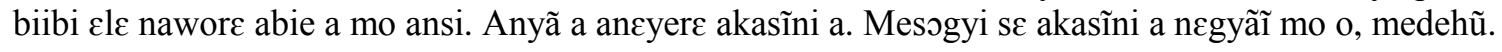

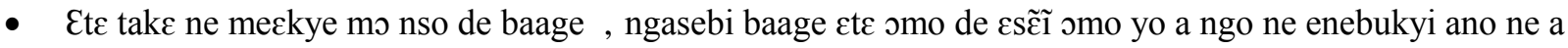
wole wore te. Baage a bo oficw paa.

\section{Story about what is planned for the next day}

Akye, ade $\varepsilon n k y e$ a, mebo otoko bo miesii so $\varepsilon t \varepsilon$ meboc.

Inde mo, me awu a mecnkye a mo ndebindebi maane bo so.

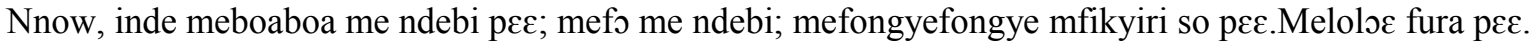

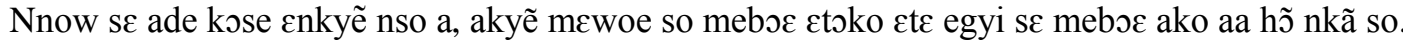

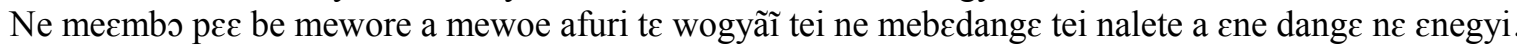

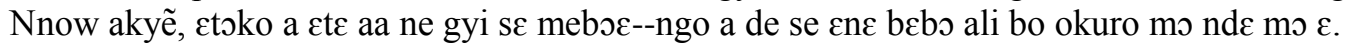

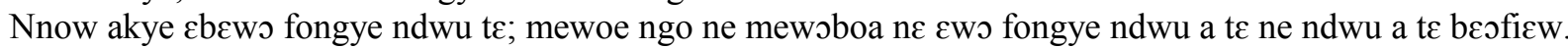

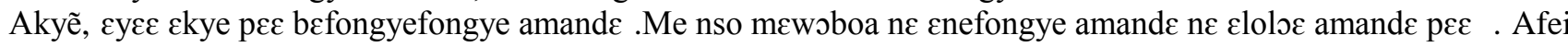

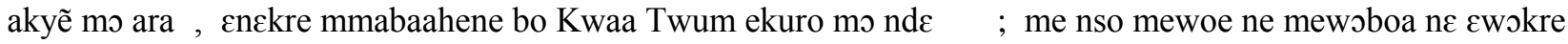

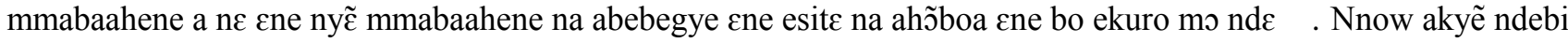

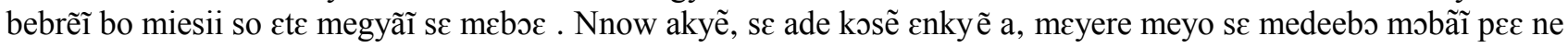

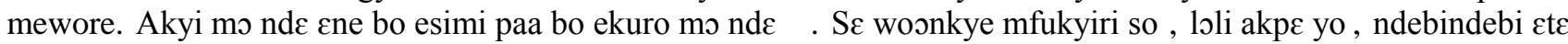

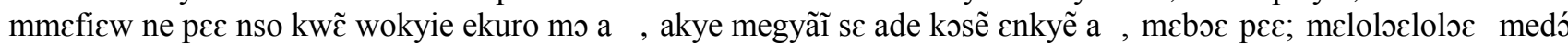
mfukyiri so, metwuw me nkangyẽẽ yo.

\section{A brief family history}

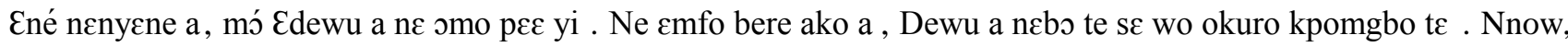

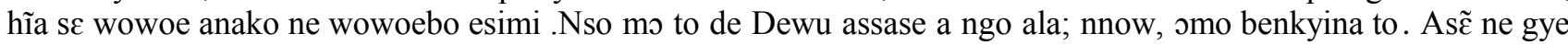

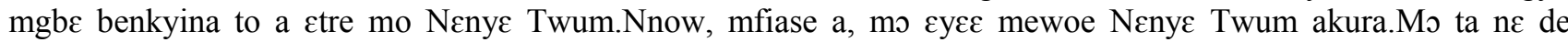

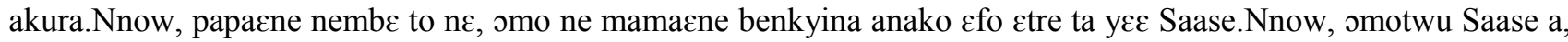

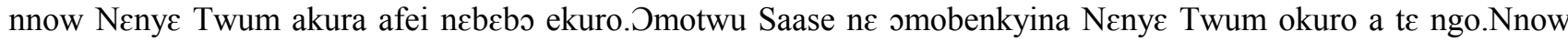

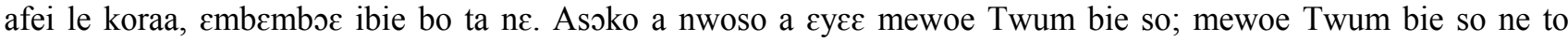

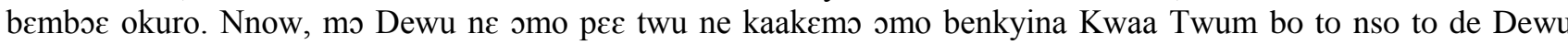
akura kpomgbo.

\section{Responses from Interviews}

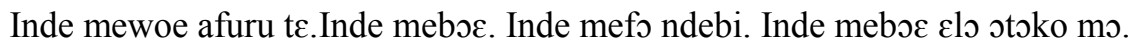

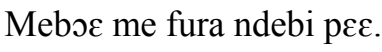

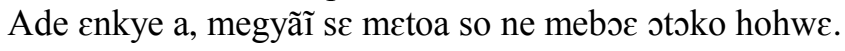

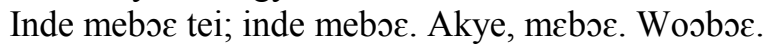

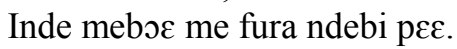

Dé me twú hõ me bi a.

Kofi dé osukuuni.

Osukuuni a dé Kofi.

Mó Kofi de osukuuni.

Kofi bò to.

\section{Kofi ne Adom}

Owura ne Owura yere Ponoma $\varepsilon w o$ ba bi a ne din de Kofi. Kofi wo okraman bi a wato ne din Adom. Adom ne Kofi

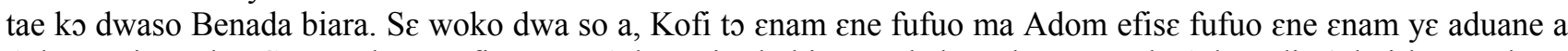
Adom ani gye ho. Enam odo a Kofi wo ma Adom nit, da biara a obeko sukuu no, ode Adom di n'akyi ko. Da koro

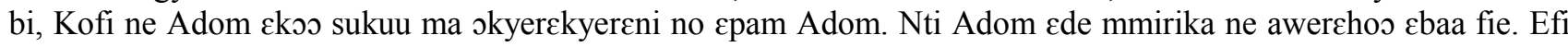
saa da no, Adom anni Kofi akyi anko sukuu bio. 